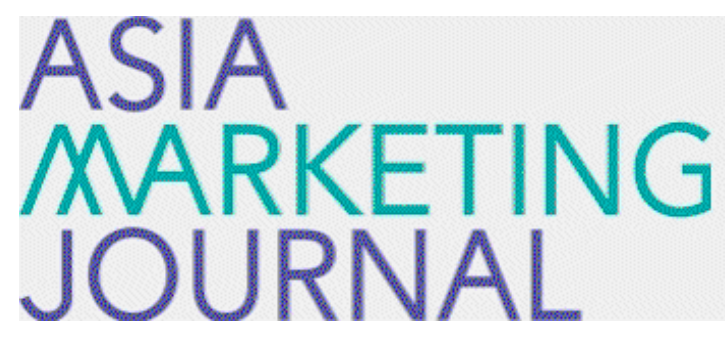

ASIA MARKETING JOURNAL

Volume 17 | Issue 4

Article 4

$1-31-2016$

\title{
K-Pop Music Worldwide and Digital Marketing Role in Brazil
}

Patricia Portugal Marques de C

Sang Yong Kim

Follow this and additional works at: https://amj.kma.re.kr/journal

Part of the Marketing Commons

\section{Recommended Citation}

C, Patricia Portugal Marques de and Kim, Sang Yong (2016) "K-Pop Music Worldwide and Digital Marketing Role in Brazil," Asia Marketing Journal: Vol. 17 : Iss. 4 , Article 4.

Available at: https://doi.org/10.15830/amj.2016.17.4.63

This Article is brought to you for free and open access by Asia Marketing Journal. It has been accepted for inclusion in Asia Marketing Journal by an authorized editor of Asia Marketing Journal. 


\title{
K-Pop Music Worldwide and Digital Marketing Role in Brazil
}

\author{
Patricia Portugal Marques de Carvalho Lourenco* \\ Sang Yong Kim**
}

$\mathrm{K}$-Pop is hugely promoted offline/online in East Asia, while efforts to promote it elsewhere are kept to a minimum. Whilst addressing the role of digital marketing in the promotion of K-Pop in the Brazilian music industry this study aims to demonstrate that K-pop will provide its audience with a unique and engaging experience if it thinks globally and acts locally in its marketing and communication strategies. A survey of K-Pop's world fan base was carried out online with 1,074 fans to determine the validity of the hypothesis. The results have demonstrated the need to adapt global and intercultural strategies to local markets with increasing brand awareness through utilizing digital marketing.

For example, to increase K-Pop's popularity and market share in Brazil, it is not required to sing in Brazilian Portuguese, contrary to what might be perceived but fully singing in English would help breaking into the market dominated by domestic music as songs would have a higher probability to be included in the international soundtrack of a Brazilian telenovela and promote the K-Pop artist not only across Brazil but also give the artist exposure in all the markets the Brazilian telenovela is exported to, opening an entry door to those markets. K-Pop audience segmentation and psychographic profiling is crucial to the understanding of each market's consumer's preferences, likes, dislikes and their buying habits as it was proven through Brazil's digital media, social media, digital music market and K-Pop market analysis within the global context of the study.

It should be also considered that brand extensions are not standard everywhere and that there are cultures where different product categories are not directly associated with its main corporate owner which requires extensive local market knowledge to succeed. The primary and secondary data research that we conducted for this study intended to demonstrate that K-Pop can be successful in Brazil and in Latin America and increase their local and regional market share if digital marketing and communication strategies are tailored to each individual market.

Key words: K-Pop, Digital Marketing, Music Promotion, Intercultural Communication, Brazil

\footnotetext{
* Instituto Superior de Comunicação Empresarial, Portugal (pat.lourenco@gmail.com)
}

** Korea University Business School (sangkim@korea.ac.kr), Corresponding Author 


\section{Introduction}

A strong component of the Korean culture promotion worldwide, K-Pop is hugely advertised across East Asia and South East Asia, yet in South America such is not the case despite a growing number of fans in the region.

This paper intends to determine the role of digital marketing in the promotion of K-Pop in Brazil and to provide the K-Pop Entertainment industry with solid research based solutions to enter domestic music dominated markets such as Brazil and demonstrate that Digital Marketing as a tool offers a vast range of possibilities for K-Pop expansion into new, non-East Asia/South East Asia Markets, generate revenue and justify an investment with financial return.

Based on two epistemological beacons: digital marketing and intercultural communication, this paper aims to interconnect them and ascertain the role of K-Pop digital marketing in Brazil. To achieve it, the role of digital marketing in the promotion of K-Pop in the Brazilian Music Industry needed to be determined and comprehended.

While Youtube reported a total of 2.3 billion $\mathrm{K}-\mathrm{Pop}$ views worldwide in 2011, from which 21 million were in Brazil (JoongAng Ilbo 2012) and those numbers increased further with Psy's "Gangnam Style", the reality is a considerable number of K-Pop artists struggle with public communication, not only in terms of speech but also in terms of content (Hong 2013). Russell (2013: 11) however argued that

'Korean labels learned early on to work with fans at the grass-roots level, building large and dynamic online communities:

Those are exported outside its home market through the internet. To be true, K-Pop artists would communicate with their global fans in English, yet that seldom happens. This study will also look at online branding aspects through its analysis as a brand in terms of identity, value, differentiation, sustainability amongst other factors that characterise it (Wheeler 2012). There is a market for K-Pop within the Brazilian music industry as proven by the number of $\mathrm{K}$-Pop views on Youtube and the fan bases of $\mathrm{K}$-Pop artists online as well as K-Pop news websites such as Soompi Brasil, part of Soompi, amongst others. A suitable digital marketing and communication strategy does need to be created to make it happen.

\section{Theoretical Background}

\subsection{Digital Marketing}

The consumer is mobile, connected 24 hours a day seven days a week, socially engaging with companies/artists/brands on the go and experiencing content on demand anywhere at 
any time.

With e-commerce, the market was restructured. A product differentiation stopped being restricted to the brand, design, quality, packaging, features, variety or size, to have digital value and improve customer experience. Marketing became more dynamic (Chaffey, D. and Smith, P.R. 2012) as new purchasing options and new models of distribution emerged, enabling customers to have access to a wider range of products from dispersed geographical areas. Despite this, the lack of international delivery or the cost and the time of international delivery remain an obstacle to many potential customers.

Marketing also started shifting towards location based offers online and price transparency. Online location based offers are tailored to specific geographic regions/areas to reach customers (Chaffey, D. and Smith, P.R. 2012) and gain their loyalty which doesn't always occur. When a customer purchases a product at a discount price once, the next time he/she might not be willing to pay the full price for it. Price transparency is a digital market demand. Price needs to be listed and transparent online and payment methods need to be clearly displayed on the website/page (Kotler, P. \& Keller, K. L. 2011; Chaffey, D. and Smith, P.R. 2012). However when it comes to foreign purchases, depending on the country of import, full price transparency might be slightly tricky due to unclear and/or unspecified import rates the product might be subjected to, resulting in an added and sometimes unplanned cost to the customer. With an overabundance of choice and information online marketing had to develop a range of techniques to promote products/services/brands/artists to the consumers. As promotional tools are vast, their choice needs to be in conformity with the digital marketing strategy of the company. Other aspects to consider as well are the scope of the promotional activities, the investment and the potential $\mathrm{re}^{-}$ turn of that investment. Local/regional/national/ international/global campaigns have different requirements/investments/infrastructure $\mathrm{re}^{-}$ quirements that need to be fulfilled and also different challenges that need to be overcome. Between Q4 2012 - Q4 2013 over 380 million people bought products online, 50 million of those in Brazil. 32 million people in Brazil and 13 million in South Korea purchase products on local deal websites proving that location based offers are a competitive way of driving the online market into excelling continuously. With electronic purchasing (e-purchasing) growing in numbers, so is social purchasing ( $\mathrm{s}$-purchasing) with $20 \%$ of internet users reporting to have purchased a product this way at the end of 2013, according to the GWI Commerce Summary (Mander 2014). The challenge however remains to use social media to drive brand engagement further, transform it into preference and convert it into loyalty, increasing sales (Banfi et al. 2013). 


\subsection{Social Media}

Facebook, Twitter and Youtube were chosen as the social platforms to be analysed in this paper as they are three of the largest social websites worldwide (Mander, J. 2014) and digital marketing promotional tools. They are also three of the biggest social media platforms in Brazil (Kemp, 2014), the country being looked at in this research paper. Facebook, a social network, whose $55 \%$ of its global audience is aged 16 - 34 years old promotes social engagement and interaction (Figure 1.1) and be the platform that ties in together all the elements of the digital marketing campaign (Zarrella, D. 2010).

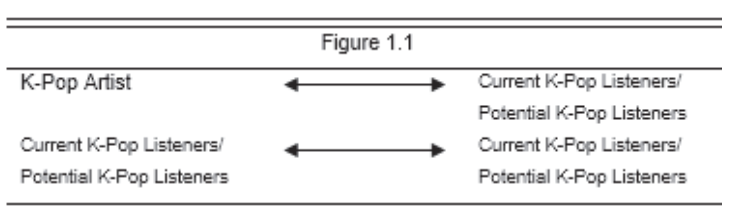

At the end of June 2014, Facebook had over 1.3 billion monthly active users, $81 \%$ of which access it on mobile. Despite a growing number of visitors/members and Facebook App usage, the number of active users on the social network has declined by 6\% between Q3 2013 Q1 2014 (Mander, J. 2014). Considering that 45\% of Facebook active users have asked their friends for advice about products they are interested in purchasing (Mander, J. 2014) it is in the artist's interest to offer subscribers/fans unique and exclusive content in their Facebook page (Zarrella, D. 2010). They will be excited and eager to like/comment/share most likely a photo (it represents $75 \%$ of the content shared worldwide on Facebook), influencing the opinions of those with whom they are friends with on the social network.

Twitter, a microblog (Zarrella, D. 2010) is used to create buzz through the distribution of content (Bradbury, D 2013); event/offers announcements or by publishing links to news stories (Kaushik, A. 2009). With a message limit of 140 characters Twitter is a power tool for companies/artists to create and engage product sales/promotion and customer relations as retweets have the ability to go viral if sent verbatim (Zarrella, D. 2010). According to a study from Converseon (EMarketeer, 2014) Twitter was considered the most positive social network globally with 55\% positive brand mentions, 20\% negative and 25\% neutral. Facebook on the other hand with $49 \%$ positive, 20\% negative and $32 \%$ neutral. Youtube, a video streaming platform and a search engine (Chaffey, D. and Smith, P. R. 2012) that actively supports video sharing (Zarrella, D. 2010) is the third largest social media platform in terms of accounts (Mander, J. 2014). With over 1 billion unique visitors monthly and over 6 billion hours of video watched in the same period of time (Youtube, 2014), Youtube is the largest social streaming website worldwide. A video uploaded onto Youtube should be promoted on social networks to gen- 
erate buzz, lead traffic to the artist website and increase sales otherwise it remains just another online entertainment site. All three social media platforms should be integrated and monitored through their KPI's and analytics. Facebook and Twitter should be linked to obtain its tweets and Youtube videos should be embedded on Facebook (Zarrella, D. 2010) to allow fans to share them easily with one another. Monitoring enables an artist to discover if their latest discussion topic, promotional event, message/video/news is a hit or not with its audience and quickly act upon it (Blanchard, O. 2011).

\subsection{Intercultural Communication}

Cross-cultural communication and globalization are linked. On one hand the world has become more standardized, on the other differences between cultures become became more evident (Guang, T. and Trotter, D. 2012), creating a need to communicate effectively in order to succeed on international markets. A common language helps achieving that and bridging cultural differences. After all, culture shapes and impacts language (Schnalke, M. and Mason, R. B. 2014). Culture also impacts consumption. Customers have different attitudes and behaviours according to their different cultures, however adjusting marketing and advertising messages to each culture is often challenging (Schnalke and Mason 2014). To increase cus- tomer engagement online, internet retailers must be culturally customized as companies still have to deliver products to customers' locations and ensure that their online content is relevant to them (Goodrich and De Mooji 2011). When ads reflect consumers' values, consumers are more likely to like the advertisements, the product brand and the enterprise. As a result the advertising campaign will be more effective (Polegato, R. and Bjerke, R. 2006). On the other hand overlooking advertising's cultural connotation could lead to a message misconception as a result there are a number of business failures in foreign markets (Guang and Trotter 2012).

Culture not only influences businesses/customers attitudes and behaviours but also advertising effectiveness. In intercultural communication marketing strategies need to be continuously adjusted to meet the specifications of the markets companies want to do business in.

\section{$2.4 \mathrm{~K}-\mathrm{Pop}$}

$\mathrm{K}$-Pop is argued to be based on European pop (Moon-Won 2014) and an imitation of mainstream western pop (Kuwahara 2014), however $\mathrm{K}$-Pop is Korean and a strong component of the country's brand that drives Korean culture expansion worldwide (Seo 2012a; Lee 2013; Russell 2013; Salmon 2013). At its core are the Korean Entertainment companies (KEC), mainly YG Entertainment, SM Entertainment and JYP Entertainment, who "manufacture" 
idols (products) and K-Pop experiences, creating the two differentiating factors the genre distinguishes itself by. Prospective idols are scouted and selected for a rigorous 5 - 7 year training program where they grow into their full potential to debut as artists, if they are found to have what it takes to succeed in this highly competitive industry. Once the training phase is completed, KEC goes into production, working with worldwide music experts to finish polishing the idols appeal and start promotional activities on a global scale, based on a triple bottom line: a symbiotic combination of songs with visuals and highly synched dance moves (Seo 2012a; 2012b). Songs are catchy, singer focused with lyrics that mix Korean sentences with short English chorus (Russell 2013; Salmon 2013); Visuals showcase fresh fashion styles with each comeback and dance moves reflect the excellence of the choreographies watched on so- $^{-}$ cial media, the medium that has projected K-Pop to a global audience. Through Facebook, Youtube and Twiter, which offer free content to users, artists are able to communicate directly with their fans (Russell 2013; Salmon 2013), increasing K-Pop's brand promotion globally (Schwartz 2011, Seo 2012b, Hong 2014) and minimizing the cost and time of entering markets overseas (Seo 2012a), a necessity considering the size of K-Pop's domestic market. Despite the strong presence across South East Asia, mostly in Japan and China, the fact remains that with the exception of PSY, K-Pop hasn't been able to succeed in markets outside its geographical region (Schwartz 2011). Tudor (2013) is sceptical about it succeeding in Western countries i.e. Europe and the US, stating that K-Pop artists try too much, as a result they end up becoming too mechanical. Non withstanding, demographically young, tech-savvy, K-Pop fans not only listen to the music but also engage with artists on their social network platforms and create $\mathrm{K}$-Pop related content, shared on social media with other K-Pop enthusiasts ( $\mathrm{Seo}$ 2012a; 2012b).

In terms of $\mathrm{K}$-Pop in Brazil, the country is geographically distant from South Korea, and as such is an expensive country to travel from to attend a K-Pop concert/fan meeting (Choi 2014). Adding to this is the cost of the event/ accommodation/food/transportation and other unplanned expenses not accounted for initially.

Despite its popularity K-Pop remains a niche market within the mainstream music sphere i.e. the Anglo-Saxon markets (United States, United Kingdom, Canada \& Australia). Those markets are four of the world top ten music markets and in 2013 generated 6.64 billion dollars in revenue, slightly over half of the value generated by the other six markets (Japan, Germany, France, Italy, Brazil and South Korea), 6.013 billion dollars (Smirke, R. 2014). The mainstream music market therefore represents millions of potential K-Pop listeners. While K-Pop songs incorporate sentences in English in their lyrics to appeal to foreign markets it's not enough 
to breach through them entirely as taste in music is intrinsic. People like music they can relate to and is close to their realities so the challenge for $\mathrm{K}$-Pop is becoming relatable in the mainstream music markets and get closer to its potential audience whilst maintaining its identity and its differentiating factor. To become relatable and get closer to potential listeners, K-Pop needs to improve its visibility and gather traditional/online media attention which requires a strong market research analysis, a solid marketing plan and an investment in terms of time and human/financial resources.

\subsection{Brazil's Media Market and Internet Usage Profile}

In Brazil the total revenue for the media \& entertainment market was US \$41 billion, a $2.4 \%$ market share of the market globally and a $42.6 \%$ share of the Latin American market (PWC, 2014). Internet subscriptions are increasing, particularly on mobile representing market opportunities to offer multi-screen content to internet users and develop or increase brand engagement. This is a result of a rise in the acquisitive power of the population, job creation and employment rates, technological development, access to credit and exemption of fiscal contributions on computers and computer parts sales.

In 2014, Brazil had a 53\% internet penetration rate, representing 108 million inhabitants (Kemp
2014). 77\% of Brazilians between the ages of 16 - 24 years old use the internet; $75 \%$ of Brazilian nationals between 10 - 15 years go online, demonstrating that internet usage rates are high between teenagers and young adults in Brazil. Percentages decrease as age increases in the country with $66 \%$ of all adults between 25 - 34 years using the internet; yet solely $47 \%$ of men and women between the ages of 35 - 44 years old go online and $44 \%$ of those whose age is over 45 years old use the internet (Jansen 2014). Of all internet users, 90\% use the internet on their laptop/pc, a percentage that has slowly been decreasing as mobile increases to $67 \%$ as a result of a growing consumer mobility. The biggest activity on mobile is video watching with 43\% (Kemp 2014).

With an average of 6 hours spent online via laptop/desktop and 2.4 hours on a mobile (Kemp 2014), young adults and teenagers spend the biggest amount of time online with 25 - 34 year olds spending $26.3 \%$ of the total of minutes on the internet and 15 - 24 years olds $26 \%$. The lowest amount of time online is spent by over 55 years old with $13.2 \%$. The 35 - 44 year olds age group spend 20.7\% and 45 - 54 years old 13.8\% (Comscore 2014). In Brazil, the Southeast region has the biggest audience in the country with $53 \%$ of the population using the internet and spending 26.2 hours online which represents a $10 \%$ growth year to year (Comscore 2014). The Southeast region is where K-Pop events take place and encompasses 
the states of Sao Paulo and Rio de Janeiro.

In Brazil Facebook, Youtube and Twitter are three of the five most popular social media platforms in the country with $68.62 \%, 21.22 \%$ and $1.63 \%$ of market share in January 2014 (eMarkeeter 2014). In Q2 2014 92\% and 59\% of Facebook and Twitter internet users respectively held an account (Kemp 2014), with the country being Youtube's fourth largest market globally (PWC 2014). Demography wise the majority of the Brazilian social media users are aged between 25 - 34 years old with $27 \%$, 18 - 24 years old with $23 \%$ and 35 - 44 years old with 20\% (Vicente 2014). On average 15 - 32 year old Brazilians have seven social networks accounts. 96\% on Facebook, 70\% on Youtube and $64 \%$ on Twitter (Rodrigues 2014). Facebook is used for chatting (Caputo 2014); Youtube to share videos and Twitter for fans to get closer to musicians/idols (Holmes 2013; Reczek 2014; Vicente 2014).

Brazil is "a nation obsessed with social networks." Cotton Delo (2013:1)

Brazilians spend 6 hours on average using social media on their laptops/desktops and 2.4 hours their mobiles (Kemp 2014), as a result of growing access to the internet and the Brazilian flair for chatting about everything as part of their culture (Chao 2009; Arno 2013; Holmes 2013; Sallowicz 2013). In Brazil nearly 40\% of social media active users watch branded videos with exclusive content as the motivation for advocating a brand globally (Global Web Index 2014). To K-Pop, Brazil offers the opportunity to strengthen its market position due to its potential to obtain a return on investment.

\subsection{Brazil's Digital Music Market and Social Media}

Brazil's generated $\mathrm{R} \$ 136.4$ million revenue digitally in 2013, a 22.39\% growth over 2012, representing a $35.46 \%$ share of the music market. $66 \%$ of those were Brazilian artists, $28.8 \%$ English speaking foreign artists and 5\% classical. Brazilians enjoy listening and singing Brazilian music and that is reflected in the music sales (Pennafort 2014; Rosa 2014). Brazil is In Latin America's biggest music market followed by Mexico, an overall geographical area whose revenues have grown $124 \%$ over the past 3 years compared to the $28 \%$ growth worldwide on average (IFPI 2014).

Brazil's economic growth, the affordability of smartphone devices and consequent expansion and the entry of new digital services in the market such as Spotify are contributing factors to a shift in the country's digital music consumption, increasingly more mobile. In Brazil Albums/single tracks downloads are the preferred method of digital music consumption with an 87\% sales increase over 2012 (Pennafort 2014; Rosa 2014). Streaming only grew 1.5\% in 2013 (Rosa 2014) yet, that is changing with the increasing number of smartphones usage in 
the country. Despite this free music acquisition remains high in a music market where $90 \%$ of all music consumption is national (IFPI 2014) with Sertanejo being either predominant and/or significant across the country and international music having a strong presence in the North, South and South East regions (Pinto 2012).

While the digital music market is stronger than ever, a positive scenario for digital music promotion, challenges concerning the market entrance in countries dominated by local repertoire such as Brazil ought to be overcome. Social media while fundamental to digital music promotion, enabling artist and fans to connect with one another, to engage and build lasting relationships, is not going to influence local repertoire dominated markets overall. A solid understanding of the music industry, specifically the digital market and an understanding of the local markets foreign artists wish to enter are vital for their successful promotion.

\section{Methodology}

\subsection{Research Methods}

Previous research has demonstrated that $\mathrm{K}$-Pop has a strong presence in South East Asia, the main focus of $\mathrm{K}$-Pop promotional activities, particularly but not exclusively Japan and China. While incorporating all geographical areas to obtain a representative sample of the population during questionnaire online promotions, there was a prior understanding that $\mathrm{K}$-Pop fans in China have a restrict access to Facebook, Google+ and Twitter which would limit almost entirely their participation in the survey. It was also understood that Japanese fan activities on the above mentioned networks would not be as extensive as in other parts of the world.

This study is a longitudinal descriptive re- $^{-}$ search which has used numerical data to describe K-Pop music as a phenomena. The research is original as previous studies on the subject have not been encountered.

\subsection{Survey}

A web survey was conducted online with 1074 random K-Pop fans worldwide via SurveyMonkey. Due to the lack of practical examples that might have serve as a starting point for the survey design, the questionnaire was elaborated from scratch with the intent of providing answers that might enable a general inference about $\mathrm{K}$-Pop worldwide and specifically K-Pop digital marketing role in Brazil. Written in English, the survey was translated into two other languages: Portuguese and Korean. English is the language the most popular K-Pop international websites use to share K-Pop information with its audience; Portuguese is Brazil's official language and Korean is the language of South 
Korea where K-Pop originates from.

Through a symbiotic combination of open-ended questions (to gather data on brand awareness, likes/dislikes and attitudes towards K-Pop) and close-ended questions (yes/no and multiple answers aimed to guide respondents towards a set of answers where to choose from) the survey intended meet the research aims and objectives. The time of completion for each questionnaire in English and Portuguese when tested was 15 minutes. Someone without prior knowledge of the questions was estimated to complete the questionnaires in either language in approximately 25 minutes. K-Pop Korean version of the questionnaire was not tested for time completion estimates. Following questionnaire development the sample size was defined using a Cochran formula to estimate it, as the total number of K-Pop fans worldwide is unknown. The objective was that the sample had the highest possible level of accuracy that could be achieved with the smallest possible size. As this study aimed to collect information pertaining $\mathrm{K}$-Pop fans in the sample aimed at having a 99\% trust with 1\% margin of error and looked at the probability that $90 \%$ of all K-Pop fans surveyed liked K-Pop. The sample size estimates provided a baseline for the web survey research. The survey was conducted in K-Pop online websites - Forums - and social networking sites - Facebook \& Google+. To conduct the surveys accurately participation in the forums/groups throughout the survey proc- ess was kept to the bare minimum.

The web survey was conducted in two phases: phase 1 - The pilot study phase, conducted between 22/10/2014 - 30/10/2014 to ascertain how many respondents would answer the questionnaires within a week's time frame and estimate the total number of replies given in four weeks. Phase 2 - the main study phase was conducted between 31/10/14 - 24/11/14 to obtain a representative sample of the population. Phase 1 had 682 responses to K-Pop questionnaire while phase 2 had $392 \mathrm{~K}$-Pop questionnaires answered. As such, K-Pop's questionnaire was filled in by 1074 respondents. The survey was answered on a global scale. Brazil's $\mathrm{K}$-Pop respondents represented $5.4 \%$ of all K-Pop respondents and $49 \%$ of South America's. Of those, 29 Brazilian nationals answered the questionnaire in Portuguese during phase 1 of the study, 15 of whom resided in Brazil. During phase 2, 42 Brazilian citizens answered the Portuguese questionnaire, 32 of whom lived in Brazil. The English questionnaire was answered by 4 Brazilian respondents during phase 1 of the study; 2 residing in Brazil, 2 in North America. During phase 2 of the study, 6 responses were obtained to the English questionnaire from Brazilian nationals, all of those residing in Brazil. The Korean version of the questionnaire obtained zero replies during phase 1 of the study and 1 reply during phase 2 . In total the K-Pop survey was distributed across 5 English speaking forums, $120 \mathrm{~K}$-Pop Facebook groups and 
31 Google+ Groups. It was also emailed to the Korean Embassy in Portugal and to Korean Cultural Centres worldwide requesting their help in promoting both questionnaires. The survey was anonymous to ensure the privacy of participants and confidentiality. Its intent was to be ethical and compliant with the regulations of good professional conduct. The survey evaluated the perceptions of K-Pop artists' communication techniques online through social media usage particularly platform description, frequency of usage, share of information/videos/ images on social networks and Facebook posts comments. To ensure that the surveys were representative of the population and reached as wide a K-Pop audience as possible, they were posted in social network groups whose main languages of communication were diverse.

All the K-Pop fans who do not have access to the internet were automatically excluded from the study as well as all the fans who did not understand English, Portuguese or Korean, those who weren't members of any K-Pop group on Facebook and Google+ and those who did not participate in the forums where the survey was published. This was taken into consideration in the elaboration of the survey.

\subsection{Challenges}

The survey had two key challenges. One, conducting an international survey in three different languages, particularly questionnaire trans- lation from the original and future back translations of English to Portuguese/Korean and Portuguese/Korean back to English; as well as the two variations of Portuguese - European and Brazilian.

Two, questionnaire coding was time consuming. The survey included a significant percentage of open-ended questions, several with a high number of variables, coded 1,074 times each; there were extensive spelling errors in the answers given i.e. countries, attributes which had to be corrected; K-Pop artists with name variations i.e. $\mathrm{K}$-Pop group TVXQ is also known as DBSK and Tohoshinki had to be addressed and aggregated together; and there was also a number of respondents who answered the survey in languages other than the ones they were asked, and the answers had to be translated into English, a factor that had not been taken into consideration when the questionnaires became available for answering online.

\subsection{Limitations}

The survey was aimed at understanding K-Pop fans, therefore the existing K-Pop audience, not contemplating general music listeners which can be potential K-Pop listeners, as the research paper looks at the world of K-Pop music and the digital marketing role in Brazil.

K-Pop Music Worldwide and Digital Marketing Role in Brazil 73 


\section{Results}

\subsection{Global}

Research findings present the results of the 1,074 survey responses in terms of demographics and subject (K-Pop, social media and communication). For the purposes of the research all countries were grouped into eight geographical areas: Europe, North America, South America, Central America, East Asia \& South East Asia, Central \& South Asia, Africa \& Middle East, and Oceania.

The K-Pop online survey was conducted with $90.6 \%$ females and $8.2 \%$ males. $50.5 \%$ of which under the age of $18.41 .1 \%$ age 19 - 25 years old; $6.2 \% 26$ - 35 years old and $0.7 \%$ for both the ages of 36 - 45 years and over 46 years old. The majority of the respondents are therefore teenagers and young adults, the majority of which female, living in Europe as demonstrated by a 56\% rate. Europe also has the highest number of respondents per nationality with $51.2 \%$ (Table 1).

$\langle$ Table 1〉

K-Pop Fans Geographical Area of Residence

\begin{tabular}{llrrrr}
\hline \hline & & & & \multicolumn{2}{c}{$\begin{array}{c}\text { Cumulative } \\
\text { Prequency }\end{array}$} \\
\hline Valid & Europe & 601 & 56.0 & 57.6 & 57.6 \\
& East Asia and South & 72 & 6.7 & 6.9 & 64.5 \\
& East Asia & & & & \\
& North America & 154 & 14.3 & 14.8 & 79.2 \\
& Central and South Asia & 15 & 1.4 & 1.4 & 80.7 \\
& South America & 121 & 11.3 & 11.6 & 92.2 \\
& Africa and Middle East & 32 & 3.0 & 3.1 & 95.3 \\
& Central America & 12 & 1.1 & 1.1 & 96.5 \\
& Oceania & 37 & 3.4 & 3.5 & 100.0 \\
& Total & 1044 & 97.2 & 100.0 & \\
Missing & 99 & 30 & 2.8 & & \\
Total & 1074 & 100.0 & & \\
\hline \hline
\end{tabular}

With the exception of North America and Oceania, the majority of the respondents residing in the other geographical areas are local nationals (Table 2).

〈Table 2〉 K-Pop Fans Geographical Area of Origin

\begin{tabular}{llrrrr}
\hline \hline & & & & \multicolumn{2}{c}{$\begin{array}{c}\text { Cumulative } \\
\text { Percent }\end{array}$} \\
\hline Valid & Europe & 550 & 51.2 & 54.6 & 54.6 \\
& East Asia and South & 128 & 11.9 & 12.7 & 67.3 \\
& East Asia & & & & \\
& North America & 92 & 8.6 & 9.1 & 76.5 \\
& Central and South Asia & 19 & 1.8 & 1.9 & 78.4 \\
& South America & 143 & 13.3 & 14.2 & 92.6 \\
& Africa and Míddle East & 36 & 3.4 & 3.6 & 96.1 \\
& Central America & 17 & 1.6 & 1.7 & 97.8 \\
& Oceania & 22 & 2.0 & 2.2 & 100.0 \\
& Total & 1007 & 93.8 & 100.0 & \\
Missing & 99 & 67 & 6.2 & & \\
Total & 1074 & 100.0 & & \\
\hline \hline
\end{tabular}

This demonstrates that in general answers were not influenced by an acculturation or enculturation process, as the majority of respondents reside in the geographical area of their nationality. Migrations within specific geographical areas were not considered in the study as the research focus is on Korean Pop music. The majority of $\mathrm{K}$-Pop fans listen to K-Pop regularly with $82.2 \%$ listening to it several times a day. (Table 3).

〈Table 3〉 K-Pop Overall Listening Frequency

\begin{tabular}{llrrrr}
\hline \hline & & & & \multicolumn{2}{c}{ Cumulative } \\
& & Frequency & Percent & Valid Percent & Percent \\
\hline Valid & Several times a day & 890 & 82.9 & 83.5 & 83.5 \\
& once day & 95 & 8.8 & 8.9 & 92.4 \\
& several times a week & 62 & 5.8 & 5.8 & 98.2 \\
& once a week & 3 & .3 & .3 & 98.5 \\
& once a month & 6 & .6 & .6 & 99.1 \\
& once every few & 10 & .9 & .9 & 100.0 \\
& months & 1066 & 99.3 & 100.0 & \\
& Total & 8 & .7 & & \\
Missing & 99 & 1074 & 100.0 & & \\
Total & & & & & \\
\hline \hline
\end{tabular}

The frequency in which fans enjoy K-Pop more than once a day is a trend across all 
eight regions. $62.8 \%$ of respondents download and listen to K-Pop on their smartphones while $58.3 \%$ do it on their Ipod/Mp3 player and 28.5\% on their PC's demonstrating an overall preference for owning the songs instead of listening to the tracks through online radio or streaming via smartphones or tablets; 26.9\%, 23.3\% and $10.6 \%$ of respondents respectively state their preference for enjoying K-Pop without having the songs on their devices. That might be due to lack of knowledge about streaming, streaming alternatives or internet speed rates in different geographical areas.

From all the artists mentioned in the survey, Big Bang was voted the favourite group of $11.1 \%$ of respondents followed by EXO with 10.9\% and BTS with 10.5\%. Big Bang being considered K-Pop's favourite artist in general and particularly in Europe, despite not releasing a new album in three years. EXO is almost equally popular, specifically in six of the eight geographical areas scrutinized in the study. It is not known whether EXO's overall popularity is due to their work which has been consistent, due to EXO-M and EXO-K, the Chinese and Korean subgroups or due to the lawsuits two former members of EXO filled against their management company to leave the group; BTS, despite being newer than Big Bang and EXO have been gathering an increasing number of fans, particularly in North and Central America, demonstrating the inexistence of a relation between years active in the industry and fanbase size. The remaining seven artist of the top ten include SHINee, 2NE1, Super Junior, B.A.P., VIXX, Girls Generation and TVXQ in that order, representing $82.6 \%$ of all respondents.

Region-wise the study only looked at the Top 3 in each of the eight regions as values were proportional to the size of each region's sample. $71.7 \%$ of fans stated that they haven't attended any of their favourite artists' concerts (Table 4).

〈Table 4〉 K-Pop Concert Attendance Rate

\begin{tabular}{llrrrr}
\hline \hline & & & & \multicolumn{2}{c}{$\begin{array}{c}\text { Cumulative } \\
\text { Percent }\end{array}$} \\
\hline Valid & No & 770 & 71.7 & 72.8 & 72.8 \\
& Yes & 287 & 26.7 & 27.2 & 100.0 \\
& Total & 1057 & 98.4 & 100.0 & \\
Missing & 99 & 17 & 1.6 & & \\
Total & & 1074 & 100.0 & & \\
\hline \hline
\end{tabular}

$37.6 \%$ of fans claimed that the artists hadn't been to where they live (Table 5).

〈Table 5〉 Not Having Held a Concert in K-Pop Fans Country as a Reason for Not Having Attended Their Favourite K-Pop Artists Concerts

\begin{tabular}{llrrrr}
\hline \hline & & & & \multicolumn{2}{c}{$\begin{array}{c}\text { Cumulative } \\
\text { Percent }\end{array}$} \\
\hline Valid & No & 333 & 31.0 & 45.2 & 45.2 \\
& Yes & 404 & 37.6 & 54.8 & 100.0 \\
& Total & 737 & 68.6 & 100.0 & \\
Missing & 99 & 337 & 31.4 & & \\
Total & & 1074 & 100.0 & & \\
\hline \hline
\end{tabular}

$15.4 \%$ saying it was a matter of money and $14.5 \%$ that it was too far. Realistically speaking an artist can't visit every city where he/she has fans in on a global level, as there countless cities worldwide. On a country level, that is 
manageable, however K-Pop's focus has been on East \& South East Asia countries, particularly on the Japanese and Chinese markets as demonstrated the partnerships that have been developed between $\mathrm{K}$-Ent agencies and Chinese agencies and by tailoring $\mathrm{K}$-Pop artists albums/songs to the Japanese market including releasing albums/songs in Japanese and having a Japanese brand name. This is due to the importance both the Chinese and the Japanese markets have for $\mathrm{K}$-Pop. In terms of markets outside that particular geographical region, concerts have been held worldwide in a few key cities. Not having the opportunity, being expensive, not having the time and living in a different country were the other reasons mentioned for not attending a concert of their favourite K-Pop artists with 8.9\%, 2.8\%, 2\% and $1.8 \%$ respectively. In Europe for example, K-Pop has been holding concerts in the continent however there haven't been many and the ones that existed are from a small number of groups, mostly held in London and Paris, with artists sometimes performing in Berlin. Munich, Dortmund, Barcelona, Milan and Stockholm have also received a K-Pop concert, however Europe is big and there are a lot of K-Pop fans in the continent that haven't had the opportunity to attend a K-Pop concert. Overall only $26.7 \%$ of fans have attended a concert of their favourite band/singer. In regards to fan meetings, the percentage of fans that have never attended one was considerably higher at $89.5 \%$ and while fans stated the same main reason for not attending the concerts with $44.7 \%$ of them mentioning their favourite artists hadn't been to their geographical area of residence. When asked if they would attend a concert/fan meeting in the country where they live, $92.6 \%$ of respondents said they would while $6.3 \%$ stated the opposite. Fans are however aware that fan meetings are rarer to occur outside East Asia \& South East Asia.

A similar percentage, 92.6\% has also mentioned to have bought/downloaded an album/ song from their favourite artist. 38.9\% have bought an album online while $34.7 \%$ have downloaded the album/song. 15.1\% of respondents purchased an album in-store and 2.9\% bought a song online (Table 6).

〈Table 6> Percentage of Fans that Have Acquired or Downloaded a K-Pop Album/Song

\begin{tabular}{llrrrr}
\hline \hline & & & & \multicolumn{2}{c}{$\begin{array}{c}\text { Cumulative } \\
\text { Percent }\end{array}$} \\
\hline Valid & $\begin{array}{l}\text { Bought algum in a } \\
\text { store }\end{array}$ & 162 & 15.1 & 16.5 & 16.5 \\
& $\begin{array}{l}\text { Bought algum in an } \\
\text { online store }\end{array}$ & 418 & 38.9 & 42.5 & 58.9 \\
& $\begin{array}{l}\text { Bought a song in an } \\
\text { online store }\end{array}$ & 31 & 2.9 & 3.2 & 62.1 \\
& $\begin{aligned} \text { Downloaded album or } \\
\text { song }\end{aligned}$ & 373 & 34.7 & 37.9 & 100.0 \\
& Total & 984 & 91.6 & 100.0 & \\
Missing & 77 & 68 & 6.3 & & \\
& 99 & 21 & 2.0 & & \\
& System & 1 & .1 & & \\
& Total & 90 & 8.4 & & \\
Total & 1074 & 100.0 & & \\
\hline \hline
\end{tabular}

$\mathrm{K}$-Pop is a niche market across most world regions and therefore physical albums/singles are harder to purchase in stores. It is however possible to purchase it in traditional retail stores worldwide i.e. Europe, North America, Oceania 
but whether albums/singles are sold in general retail stores in those regions or in specific Korean stores it is unknown. Solely $6.3 \%$ of respondents mentioned they have never bought/downloaded an album/song from their favourite K-Pop artist.

Globally K-Pop is also streamed by $62.4 \%$ of fans on their PC's, laptops, smartphones and tablets by most K-Pop fans globally, not a great percentage higher from region to region, what might be due to Youtube. With $21.4 \%$ of responses, the social network is not only an ad-supported video streaming platform but also the most used one amongst all respondents who overall like to enjoy watching K-Pop videos. Spotify with $2.3 \%$ and iTunes with $1.5 \%$ were also mentioned with $34.5 \%$ of respondents have stating that they don't stream K-Pop music. The majority of fans watch K-Pop videos regularly with $58.8 \%$ saying that they watch them several times a day, $18.8 \%$ several times a week and 13.6\% once a day. Only 4.9\%, 1.6\% and $1.4 \%$ of fans watch $\mathrm{K}$-Pop videos once a week, once a month and once every few months respectively. Videos are watched nearly exclusively on Youtube by $97.7 \%$ of fans. The percentage confirmed the platform's status as the reference video streaming social media for $\mathrm{K}$-Pop fans. When asked to define their favourite artists in three words, the most mentioned were talented, funny and perfect with $29.1 \%, 12.6 \%$ and $12.3 \%$ of responses respectively.

Overall K-Pop as a brand is perceived the way it is intended to be perceived, for the mu- sic, the choreographies and the singing. Liking it is the main reason for liking K-Pop according to $91.5 \%$ of fans. Liking the choreography, the way artists sing and the beat are also highly mentioned by $77.8 \%, 72.2 \%$ and $70.9 \%$ of re- $^{-}$ spondents, respectively. $62.2 \%$ of fans like K-Pop because they like the lyrics while $59.6 \%$ of fans like it because the members are good looking and $53.9 \%$ because of how they dress. Only $1.7 \%$ of fans like their artists because they are Korean with the majority of fans also mentioned they would like their favourite artists if they weren't Korean with $76.4 \%$ responses while $3.4 \%$ mentioned that they wouldn't like their favourite artists if they weren't.

$\mathrm{K}$-Pop has also changed the way 98.4\% of respondents see Korean culture/Korean people. If $\mathrm{K}$-Pop artists had a comeback in a language other than Korean, the majority of fans, 68.5\% of them to be exact stated that it ought to be English (Table 7).

$\langle$ Table 7〉 Language Other Than Korean Fans would like Their Favourite K-Pop Artists To Sing In

\begin{tabular}{llrrrr}
\hline \hline & & & & \multicolumn{2}{c}{$\begin{array}{c}\text { Cumulative } \\
\text { Percent }\end{array}$} \\
\hline Valid & English & 736 & 68.5 & 72.2 & 72.2 \\
& Spanish & 72 & 6.7 & 7.1 & 79.2 \\
& Portuguese & 44 & 4.1 & 4.3 & 83.5 \\
& Mandarim & 68 & 6.3 & 6.7 & 90.2 \\
& Japanese & 47 & 4.4 & 4.6 & 94.8 \\
& Others & 53 & 4.9 & 5.2 & 100.0 \\
& Total & 1020 & 95.0 & 100.0 & \\
Missing & 99 & 54 & 5.0 & & \\
Total & & 1074 & 100.0 & & \\
\hline \hline
\end{tabular}

That makes sense considering that English is the language most respondents are fluent in 
and understand. If some K-Pop artists sing in Japanese in Japan and others have Chinese sub-units to reach those two markets, singing in English would not only enable $\mathrm{K}$-Pop to reach Europe and North America but also reach a wider audience. The other languages mentioned, albeit in a very small way were Spanish, Portuguese, Mandarin and Japanese.

$11.6 \%$ of fans indicated that their favourite $\mathrm{K}$-Pop band/singer does not have a website while the majority - $85.6 \%$ of fans stating the opposite. $85.1 \%$ of respondents have also visited their favourite artist's website. Using a 1 - 5 Likert scale, respondents were asked to classify fourteen statements about the website. $11.3 \%$ of fans wholeheartedly agree that their favourite K-Pop artist's website looks good and is well organized and 6.9\% think it's easy to browse through. $7.9 \%$ fully agree that the gallery section has high quality photos and 3.7\% that the website is informative and well organized. $3.7 \%$ also agree a lot that the website has an updated a full album list, despite 2.2\% being unsure on whether the album/songs are available for onsite purchasing or have links to external websites where they can be purchased from. However $2.9 \%$ of fans agree that the songs with music videos have links to where they can be watched online. $2.6 \%$ are in agreement that the website has a news section with updated information on concert tours and fan meetings worldwide and $1.8 \%$ are of the same opinion in regards to the provision of links to where fans can purchase concert/fan meeting tickets from. 3.3\% of fans are in full agreement that the website has an English version and $1.6 \%$ also fully agree that it's well written without any spelling or grammar mistakes. Fans however are not certain as to whether the English version has the same amount of information that the Korean version has with 2.2\% of responses and a similar percentage entirely disagreeing with the statement. Fans are also unsure about whether the website has a forum/ message board accessible to login for non-Koreans and whether the website has a download section with free banners and screensavers.

Facebook, Youtube and Twitter with 52.9\%, $27.2 \%$ and $12.2 \%$ respectively are the most popular social media for fans and K-Pop artists. Fans chat to friends and watch videos online either on a PC/laptop or smartphone with 51.1\% of them spending more than 3 hours a day on social media; $22 \%$ spend 2 - 3 hours, 19.6\% 1 - 2 hours and $4.3 \%$ less than an hour daily. Fans also check their social networks regularly with $47.8 \%$ of K-Pop fans go on social media several times a day while $36.7 \%$ do it once a day. $9.8 \%$ and $2.9 \%$ visit social media several times a week and once a week respectively, reflecting the demographics. Teenagers and young adults have more free time than an average working adult. K-Pop artists, as nearly all respondents follow their favourite artists on social media, particularly on the top three mentioned above, it's important to keep them regularly 
updated with content.

$74.1 \%$ of respondents also share information/ videos/images/news about their favourite artists on social media as opposed to $23.4 \%$ that don't (Table 8).

〈Table 8> Percentage of K-Pop Artists Information/ Videos/Images/news Sharing by Fans of Social Media

\begin{tabular}{llrrrr}
\hline \hline & & & & \multicolumn{2}{c}{$\begin{array}{c}\text { Cumulative } \\
\text { Percent }\end{array}$} \\
\hline Valid & No & 251 & 23.4 & 24.0 & 24.0 \\
& Yes & 796 & 74.1 & 76.0 & 100.0 \\
& Total & 1047 & 97.5 & 100.0 & \\
Missing & 99 & 27 & 2.5 & & \\
Total & & 1074 & 100.0 & & \\
\hline \hline
\end{tabular}

The preferred networks are Facebook, Twitter, Youtube, Instagram, Tumblr and Google+ with $58 \%, 40.1 \%, 18 \%, 7.2 \%, 6.5 \%$ and $5 \%$ respectively. $51.9 \%$ of fans also comment on their favourite artists posts on Facebook. 45.6\% said that they don't what might be due to the language barrier. From the K-Pop fans that comment, 68.2\% stated that the posts are not written exclusively in Korean while 28\% disagrees.

It ought to be understood that $70 \%$ of $\mathrm{re}^{-}$ spondents have stated that they don't speak/ understand Korean (Table 9), having to rely on either the possibility that the one of the previous posts is has a translation, use an online translator or use fan pages for translations with $53.3 \%, 25 \%$ and $4 \%$ of fans respectively to understand the message being shared. 10.1\% believe their favourite K-Pop artist doesn't communicate well with their fans, stating the language barrier and not updating social media networks (Table 10).

〈Table 9> Percentage of K-Pop Fans that Either Speak or Understand Korean

\begin{tabular}{llrrrr}
\hline \hline & & & & \multicolumn{2}{c}{$\begin{array}{c}\text { Cumulative } \\
\text { Percent }\end{array}$} \\
\hline Valid & No & 752 & 70.0 & 72.1 & 72.1 \\
& Yes & 291 & 27.1 & 27.9 & 100.0 \\
& Total & 1043 & 97.1 & 100.0 & \\
Missing & 99 & 31 & 2.9 & & \\
Total & & 1074 & 100.0 & & \\
\hline \hline
\end{tabular}

〈Table 10〉 K-Pop Fans Methods to Try to Understand Their Favourite K-Pop Artists Posts on Social Media

\begin{tabular}{|c|c|c|c|c|c|}
\hline & & Frequency & Percent & Valid Percent & $\begin{array}{l}\text { Cumulative } \\
\text { Percent }\end{array}$ \\
\hline \multirow[t]{4}{*}{ Valid } & $\begin{array}{l}\text { Read previous posts } \\
\text { to see if there's a } \\
\text { translation }\end{array}$ & 355 & 33.1 & 53.3 & 53.3 \\
\hline & $\begin{array}{l}\text { Use an online } \\
\text { translator }\end{array}$ & 268 & 25.0 & 40.2 & 93.5 \\
\hline & $\begin{array}{l}\text { Use fan's pages for } \\
\text { translations }\end{array}$ & 43 & 4.0 & 6.5 & 100.0 \\
\hline & Total & 666 & 62.0 & 100.0 & \\
\hline \multirow[t]{3}{*}{ Missing } & 77 & 291 & 27.1 & & \\
\hline & 99 & 117 & 10.9 & & \\
\hline & Total & 408 & 38.0 & & \\
\hline Total & & 1074 & 100.0 & & \\
\hline
\end{tabular}

〈Table 11〉 Languages Fans Would Like Their Favourite K-Pop Artists to Communicate to Them In

\begin{tabular}{llrrrr}
\hline \hline & & & & \multicolumn{2}{c}{$\begin{array}{c}\text { Cumulative } \\
\text { Percent }\end{array}$} \\
\hline Valid & English & 882 & 82.1 & 85.5 & 85.5 \\
& Spanish & 52 & 4.8 & 5.0 & 90.6 \\
& Portuguese & 47 & 4.4 & 4.6 & 95.2 \\
& Mandarim & 8 & .7 & .8 & 95.9 \\
& French & 17 & 1.6 & 1.6 & 97.6 \\
& Korean & 11 & 1.0 & 1.1 & 98.6 \\
& Others & 14 & 1.3 & 1.4 & 100.0 \\
& Total & 1031 & 96.0 & 100.0 & \\
Missing & 99 & 43 & 4.0 & & \\
Total & 1074 & 100.0 & & \\
\hline \hline
\end{tabular}

English was the chosen language K-Pop fans would like their favourite band/singer to communicate to them in as chosen by $82.2 \%$ of respondents (Table 11). 83.1\% of respondents also stated that they would engage more with 
their favourite artist on social media should the artists speak in a language they understand (Table 12).

〈Table 12〉 Should K-Pop Artists Communicate with Their Fans in a Language Fans Understand, Fan Engagement Rate Would Be Higher

\begin{tabular}{llrrrr}
\hline \hline & & & & \multicolumn{2}{c}{$\begin{array}{c}\text { Cumulative } \\
\text { Percent }\end{array}$} \\
\hline Valid & No & 151 & 14.1 & 14.5 & 14.5 \\
& Yes & 892 & 83.1 & 85.5 & 100.0 \\
& Total & 1043 & 97.1 & 100.0 & \\
Missing & 99 & 31 & 2.9 & & \\
Total & & 1074 & 100.0 & & \\
\hline \hline
\end{tabular}

\subsection{Brazil}

Brazil's demographics are similar to the survey's overall demographics, mostly females under 25 years of age. 62 Brazilian K-Pop fans are mostly teenagers age, 14 - 20 years old financially dependent on their parents. Even with part-time jobs, held by a number of them, their earnings are insufficient to afford a K-Pop fan meeting/concert or an original K-Pop CD/ DVD. Following a global trend K-Pop is mostly downloaded on smartphones in Brazil, followed by iPopd/MP3 players and online radio, making the digital audio a more popular medium to listen to K-Pop in Brazil than a PC. Streaming is also not significant in the country. This might be due to two reasons: one, downloading habits and two, the novelty of streaming in the country, which is considerably recent. When done, Youtube is the chosen platform for streaming. SHINee, EXO, Super Junior and TVXQ are K-Pop's favourite artists in Brazil. Comparing to the global results, TVXQ appear in the top 3 along with Super Junior while worldwide they rank tenth place. In addition, Big Bang who is globally ranked first, in Brazil rank fourth place alongside 2NE1 and BTS. Brazil's unique ranking is related to the fact that SHINee performed in Brazil during Music Bank in 2014 and Super Junior held a concert in Brazil in 2013. Note that SHINee, Super Junior, EXO and TVXQ are all represented by the same management company: SM Entertainment that is recognized worldwide for its work. Talented and perfect are the two words Brazilian fans use to describe their favourite band/singer. Brazilian fans would also attend a concert/fan meeting where they live. Most would also pay more than $\mathrm{R} \$ 121,00$ for a K-Pop concert ticket. ${ }^{1)}$

As concerts/fan meetings are sporadic in Brazil, fans watch $\mathrm{K}$-Pop videos on Youtube several times a day in their majority.

Their love for K-Pop is about the music, the beat and the choreography most of all. The fact that their favourite band/singer is Korean doesn't matter to them but K-Pop did change how they see Korean people/Korean culture. Native Portuguese speaking fans however would

1) This question was not part of the survey. It was done afterwards to random Brazilian K-Pop fans in a K-Pop Facebook group as it was noticed that the question ought to be asked. The results are inserted here as they are important for the research but they should be read independently. 
prefer their favourite artists to have a comeback album in English (Table 13), surprisingly not in Portuguese.

〈Table 13〉 Language other than Korea Brazilian K-Pop Fans would like their Favourite K-Pop Artists to Sing in

\begin{tabular}{llrrrr}
\hline \hline & & & & \multicolumn{2}{c}{$\begin{array}{c}\text { Cumulative } \\
\text { Percent }\end{array}$} \\
\hline Valid & English & 34 & 54.8 & 58.6 & 58.6 \\
& Spanish & 2 & 3.2 & 3.4 & 62.1 \\
& Portuguese & 17 & 27.4 & 29.3 & 91.4 \\
& Japanese & 5 & 8.1 & 8.6 & 100.0 \\
& Total & 58 & 93.5 & 100.0 & \\
Missing & 99 & 4 & 6.5 & & \\
Total & 62 & 100.0 & & \\
\hline \hline
\end{tabular}

All 85.5\% Brazilian respondents who have stated that their favourite artist has a website have visited it, albeit only a small fraction of them have rated it in terms of appearance and content. The low values and response rates are nonetheless consistent with the overall values of the K-Pop survey.

$38.7 \%$ of $\mathrm{K}$-Pop fans in Brazil access social media networks on their PC's, 9\% more than the global average; with only 29\% accessing it on their laptop and equally on their smartphones, values that are lower than the overall average. Brazil's tablet usage is null.

Brazil's results are representative of the population as the fixed internet rate in the country is higher than the global average and Brazil's mobile internet access is growing. Facebook, Youtube and Twitter are the most popular social network in the country with $61.3 \%, 14.5 \%$ and $12.9 \%$ respectively.
Facebook values are higher than average, as $38.7 \%$ of respondents use social media to talk to their friends (Table 14); Youtube's percentages are considerably lower, reflecting the $19.4 \%$ of Brazilian K-Pop fans that use social networks to watch videos and Twitter's values are $0.7 \%$ higher.

〈Table 14〉 Reasons Why Brazilian K-Pop Fans Use Social Networks

\begin{tabular}{|c|c|c|c|c|c|}
\hline & & Frequency & Percent & Valid Percent & $\begin{array}{c}\text { Cumulative } \\
\text { Percent }\end{array}$ \\
\hline \multirow[t]{6}{*}{ Valid } & Speak to friends & 24 & 38.7 & 42.9 & 42.9 \\
\hline & Watch videos & 12 & 19.4 & 21.4 & 64.3 \\
\hline & Share images/videos & 10 & 16.1 & 17.9 & 82.1 \\
\hline & $\begin{array}{l}\text { Follow KPop and KPop } \\
\text { fans }\end{array}$ & 3 & 4.8 & 5.4 & 87.5 \\
\hline & All & 7 & 11.3 & 12.5 & 100.0 \\
\hline & Total & 56 & 90.3 & 100.0 & \\
\hline Missing & 99 & 6 & 9.7 & & \\
\hline Total & & 62 & 100.0 & & \\
\hline
\end{tabular}

$71 \%$ of Brazilian respondents spend more than 2 hours a day on social media, 2.5\% less than global average, yet from those 71\%, 61.3\% spend more than 3 hours on social networks, compared to $51.5 \%$ of global respondents (Table 15 ).

〈Table 15〉 Brazilian K-Pop Fans Times Spent on Social Media Per Day

\begin{tabular}{llrrrr}
\hline \hline & & & & \multicolumn{2}{c}{$\begin{array}{c}\text { Cumulative } \\
\text { Percent }\end{array}$} \\
\hline Valid & less than 1hr & 3 & 4.8 & 5.0 & 5.0 \\
& 1 to 2hrs & 13 & 21.0 & 21.7 & 26.7 \\
& 2 to 3hrs & 6 & 9.7 & 10.0 & 36.7 \\
& More than 3hrs & 38 & 61.3 & 63.3 & 100.0 \\
& Total & 60 & 96.8 & 100.0 & \\
Missing & 99 & 2 & 3.2 & & \\
Total & 62 & 100.0 & & \\
\hline \hline
\end{tabular}

43.5\% K-Pop Brazilian fans visit social media several times a day, less $4.3 \%$ than global average while $40.3 \%$ visit it at least once a day, 3.6\% 
more than the overall survey results. Therefore, despite spending over three hours daily on social networks, Brazilian fans access it less regularly throughout the day.

95.2\% of Brazilian fans follow their favourite K-Pop artists on social media, $80.6 \%$ of which on Facebook, 79\% on Youtube, $74.2 \%$ on Twitter and $27.7 \%$ on Instagram. $75.8 \%$ of respondents comments on their favourite artist posts on Facebook which $72.6 \%$ of fans state are not written solely in Korean. Percentages are slightly higher than average, demonstrating that in Brazil K-Pop fans have a higher level of social media engagement than $\mathrm{K}$-Pop fans in general.

77.4\% of Brazilian K-Pop fans do not speak/ understand Korean with 53.3\% of respondents saying that they read previous posts to see if there is a translation that they can understand (Table 16). The use of online translators and fan pages for translations are only used by a small percentage of fans.

〈Table 16〉 Brazilian K-Pop Fans Methods to Try to Understand Their Favourite K-Pop Artists Posts on Social Media

\begin{tabular}{llrrrr}
\hline \hline & Frequency & Percent & Valid Percent & \multicolumn{2}{c}{$\begin{array}{c}\text { Cumulative } \\
\text { Percent }\end{array}$} \\
\hline Valid & $\begin{array}{l}\text { Read previous posts } \\
\text { to see if there's a }\end{array}$ & 33 & 53.2 & 84.6 & 84.6 \\
translation & & & & \\
& $\begin{array}{l}\text { Use an online } \\
\text { translator }\end{array}$ & 4 & 6.5 & 10.3 & 94.9 \\
& $\begin{array}{l}\text { Use fan's pages for } \\
\text { translations }\end{array}$ & 2 & 3.2 & 5.1 & 100.0 \\
& Total & 39 & 62.9 & 100.0 & \\
Missing & 77 & 12 & 19.4 & & \\
& 99 & 11 & 17.7 & & \\
Total & Total & 23 & 37.1 & & \\
\hline \hline
\end{tabular}

$53.2 \%$ of respondents are fluent in English and $66.1 \%$ understand the language.

As English is spoken in cities like Rio de Janeiro and Sao Paulo, who have large foreign communities, larger incomes and sizeable K-Pop communities, it might be inferred that respondents who are fluent in English reside in those areas. Only $14.5 \%$ of respondents think K-Pop artists communicate well with fans through their social networks regular updates. The reason why fans believe K-Pop artists do not communicate well with their fans is the language barrier.

Overall, findings revealed that $\mathrm{K}$-Pop is mostly listened by female teenagers and young adults up to the age of 25 years old that prefer downloading K-Pop music on their devices rather than streaming music. Fans do stream videos almost exclusively on Youtube, one of the three most used social media networks along with Facebook and Twitter. Respondents state that K-Pop bands/ singers are perfect and that's what matters. Fans like them not because of their nationality but because of the music, the dance and the singing which for the most part match the qualities they perceive their favourite artists to have. As Korean is not a language many respondents are fluent in and it's level of understanding is variable, English is the language chosen for the artists comebacks, as it's not only a common language worldwide but also is the language most fans are fluent in and understand. Fans like engaging with artists on social media, mostly in English. 


\subsection{Overall Results Assessment}

Results have proven that for K-Pop to be successful worldwide in mainstream music markets and in those that like Brazil consume nearly exclusive local music it needs to be mindful of cultural differences and develop marketing strategies specifically tailored to those markets, in order to acquire more fans and increase both its market share and revenue. Digital platforms such as Facebook, Youtube and Twitter play a crucial role in K-Pop's promotion worldwide as well as in Brazil, as tools to not only showcase K-Pop to potential customers but also to engage with current fans. While Korean language might be a barrier to the effective communication within the mainstream music markets, is also a differentiating factor which must be kept as it is an intrinsic factor of $\mathrm{K}$-Pop as a brand and as a product. This challenge can easily be overcome on social media as the survey re- $^{-}$ spondents have stated that they would engage more with their favourite K-Pop artists if they communicated with them in a language they understand, which is English, the language that dominates mainstream pop music. If for example music videos and interviews given by K-Pop artists and uploaded online have English subtitles from the start (there is an option on Youtube which enables the adding of subtitles if they're available) then fans would engage a lot more, would promote K-Pop to their friends a lot more and enable $\mathrm{K}$-Pop to reach a wider audience and acquire more fans, promoting Korea as a brand and strengthening its brand value worldwide. Also, the cost of the translation would be paid off with an increase in fans engagement rate and potential customer acquisition. To support this having a local distribution centre would be an added value as customers would be able to pay reasonable prices for K-Pop related merchandise without the often heavy import taxes which make it more expensive. That distribution centre could also distribute K-Pop products to local music stores, making them locally available not only to existing K-Pop customers but also to potential $\mathrm{K}$-Pop customers.

\section{Conclusion}

Brazilian responses are not overly different from the global survey results, despite its 90\% local music consumption rate. This leaves 10\% for international music, exclusively sang in English. K-Pop is a niche market in the country, specifically within the 10\% English dominated music as such, in order to flourish in Brazil the K-Pop Entertainment industry needs to understand how the music market works and how to communicate effectively in the country to succeed. Once that is grasped and fully comprehended, K-Pop needs to develop partnerships with local artists to increase its local 
visibility and start promoting locally not only on digital media but also on traditional media in a blended marketing campaign. If a K-Pop artist for example participates in a Brazilian telenovela as guest actor and maybe as a singer that will contribute to the promotion of the artist, K-Pop's and the Korea brand in Brazil as telenovelas are watched by a significant percentage of the Brazilian population. If $\mathrm{K}$-Pop has specific promotional methods tailored to Japan, why not having them tailored to Brazil? It would create long-term relationships with the country's domestic music industry, increase its fan base and boost K-Pop and Korea's brand awareness in the strongest markets in Latin America. ${ }^{2)}$

To increase K-Pop's popularity and market share in Brazil, it is not required to sing in Brazilian Portuguese, contrary to what might be perceived but fully singing in English would help breaking into the market dominated by domestic music as songs would have a higher probability to be included in the international soundtrack of a Brazilian telenovela and promote the K-Pop artist not only across Brazil but also give the artist exposure in all the market the Brazilian telenovela is exported to, opening an entry door to those markets. K-Pop audience segmentation and psychographic profiling is crucial to the understanding of each market's consumer's preferences, likes, dislikes and their buying habits as it was proven through Brazil's digital media, social media, digital music market and K-Pop market analysis within the global context of the study. This study shows that it is important for differentiating K-Pop's domestic market and K-Pop within the Japanese market from the other K-Pop existing and potential global markets. It ought to be understood that K-Pop as a brand despite being cohesive overall and matching the perceptions it wishes to instil in its audience. This means different things to different people across different cultures which ought to be reflected in its local promotions as a brand and as a product to further maximize its profitability. It should be also considered that brand extensions are not standard everywhere and that there are cultures where different product categories are not directly associated with its main corporate owner which requires extensive local market knowledge to succeed. The primary and secondary data research that we conducted for this study intended to demonstrate that K-Pop can be successful in Brazil and in Latin America and increase their local and regional market share if digital marketing and communication strategies are tailored to each individual market. In conclusion, this study raised the importance of K-Pop adapting global and intercultural strategies to local non-East and South East Asia markets with expanding brand awareness through

2) Latin America incorporates all South America \& Central America markets including Mexico, Chile and Peru. 
utilizing digital marketing.

It would be interesting to explore K-Pop in Brazil from a regional perspective and deepen the research from the global level on which $\mathrm{K}$-Pop was studied in the country to a regional one to ascertain if K-Pop's digital marketing and intercultural communication strategies need to be adjusted to the region instead of just the country.

\section{Implications for Future Research \& for Society}

Through the theoretical analysis of Digital Marketing and Intercultural Communication as conceptual frameworks and their blending with $\mathrm{K}$-Pop Music, the research paper intended to demonstrate that marketing strategies need to be locally tailored not only to maintain K-Pop's existing fan base but to enlarge it through new fan acquisition and increase K-Pop financial revenue worldwide. Fans and potential fans (K-Pop's potential customers) offer Korea the opportunity to gain visibility as a brand and to promote its culture, domestic brands and products through it without an added investment, therefore without an extra cost.

As we currently live in a society constantly connected online, this represents billions of potential K-Pop customers worldwide. Brazil, has over 200 million inhabitants, over 200 million
K-Pop potential fans, potential Korean culture/ technology consumers. To reach them, Korea as a brand needs to be known in the country. Brazilians love music. K-Pop is Korean Pop Music. As such, with the right marketing strategy, $\mathrm{K}$-Pop can pave the way for the Korean enterprises to reach those millions of Brazilian potential customers.

〈Received October 27. 2015〉

〈Revised December 8. 2015〉

〈Accepted January 4. 2016〉

\section{References}

Arno, C. (2013) Brazil: A social media marketeers's gold mine. Social Media Today. [Online] $5^{\text {th }}$ April 2013. Available from: http://socialmediatoday.com/christian-arno /1337541/brazil-social-media-marketinggold-mine. [Accessed: 20 December 2013].

Banfi, F. et al. (2013) E-Journey: Digital Marketing and the "Path to Purchase". [Online] Number 22 Recall. McKinsey \& Company. Available from: http://www.mckinsey.com/ client_service/marketing_and_sales/latest _thinking/ejourney_digital_marketing__ and_path_to_purchase [Accessed 20 January 2014].

Caputo, V. (2014) Brasil e superado por 17 paises em adoção de redes sociais. [Online]. Exame. 14 February 2014. Available from: http: 
//exame.abril.com.br/tecnologia/noticias/ brasil-e-superado-por-17-paises-emuso-deredes-sociais [Accessed: 06 June 2014].

Chaffey, D. and Smith, P. R. (2012) Emarketing Excellence: Planning and Optimizing your Digital Marketing. $4^{\text {th }}$ Ed. Oxon: Routledge. Chao, L. (2013) Brazil the social media capital of the universe. The Wall Street Journal. [Online] $4^{\text {th }}$ February 2013. Available from: http://online.wsj.com/news/articles/SB100 01424127887323301104578257950857891898 [Accessed 18 ${ }^{\text {th }}$ December 2013].

Choi, J. B. and Maliangkay, R. (2014) K-Pop - The International Rise of the Korean Music Industry. Oxon: Routledge.

Comscore (2014) 2014 Brazil Digital Future in Focus. [Online]. Comscore. Avaliable from: http://www.comscore.com/Insights/ Presentations-and-Whitepaper [Accessed: 12 July 2014].

Cotton, D. (2013) In Brazil, Facebook, Twitter Battle for Ad Dollars as Social Land Heats Up: A Nation Obsessed with Social Networks. [Online]. Ad Age. 28 February 2013. Available from: http://adage.com/article/digital/brazil - s-big-social-media-land-grab-heats/240061 /[Accessed: 4 June 2014].

eMarketeer (2014) Articles. [Online]. eMarketeer. Available from: http://www.emarketer.com/ Articles [Accessed: 04 October 2014].

Goodrich, K. and De Mooji, M. (2011) New Technology Mirrors Old Habits: Online Buying Mirrors Cross-National Variance of
Conventional Buying. Journal of International Consumer Marketing. 23:246-259.

Guang, T. \& Trotter, D. (2012) Key Issues in Cross-Cultural Business Communication: Anthropological Approaches to International Business. African Journal of Business Management. 8 (22). P. 6456-6464.

Holmes, R. (2014) Brasil, Capital Mundial das Midias Sociais. [Online]. Hotsuite. Available from: http://blog.hootsuite.com/brazil-futuresocial-forbes-portuguese/ [Accessed: 12 October 2014].

Hong, Seok-kyeong (2013) in Lee Sun-Min (2013) Can K-pop prove it's got staying power? Korea JoongAng Daily. [Online] 28 August 2013. Available from: http://koreajoongangdaily. joins.com/news/article/article.aspx?aid = 2976717. [Accessed 12 February 2014].

International Federation of the Phonographic Industry (2014a) IFPI Digital Music Report 2014: Lighting Up New Markets. IFPI [Online]. Available from: http://www.ifpi. org/downloads/Digital-Music-Report-2014. pdf. [Accessed 31 March 2014].

Jansen, T. (2014) Numero de Internautas no Brasil alcanca percentual inédito, mas acesso ainda e concentrado. [Online]. 26 June 2014. Available from: http://oglobo.globo. com/sociedade/tecnologia/numero-deinternautas-no-brasil-alcanca-percentualinedito-mas-acesso-ainda-concentrado13027120 [Accessed: 15 October 2014]. JoongAng Ilbo (2012) Youtube views 2011. In 
Soompi (2012) KPop Videos Set New Record on Youtube. [Online] $2^{\text {nd }}$ January 2012. Available from: http://www.soompi.com/ 2012/01/02/kpop-videos-set-new-recordon-youtube/\#.Uzh9x_ldXd0. [Accessed: 20 January 2014].

Kemp, S. (2014) Digital in the Americas. We Are Social's Snapshot of Key Digital Statistics and Data.

Kotler, P. and Keller, K. L. (2011) Marketing Management. $14^{\text {th }}$ Ed. Upper Saddle River: Prentice Hall.

Kuwahara, Y. (2014) The Korean Wave: Korean Popular Culture in Global Context. New York: Palgrave Macmillan.

Mander, J. (2014) GWI Commerce Summary Q2 2014. Global Web Index.

Moon-Won, L. (2014) in Hong, E. (2014) The Birth of Korean Cool: How One Nation is Conquering the World Through Pop Culture. New York: Picador.

Pennafort, R. (2014) Mercado da Musica Digital cresceu 22.39\% em 2013 em relação a 2012. Estadao. [Online]. 19 $9^{\text {th }}$ March 2014. Available from: http://estadao.br.msn.com/ cultura/mercado-de-m\%c3\%BAsica-digital - cresceu-2239percent-em-2013-em-rela\% C3\%A7\%C3\%A30-a-2012-1. [Accessed 25 ${ }^{\text {th }}$ March 2014].

Pinto, G. L. (2012) A Musica que Da Gosto. Sistemas \& Gestao. 7 (2) pp. 240-260.

Polegato, R. and Bjerke, R. (2006) in De Mooji, M. and Hofstede, G. (2010) The Hofstede model: Applications to global branding and advertising strategy and research. International Journal of Advertising. 29 (1), pp. 85-110.

PWC (2014) Global Entertainment and media Outlook 2014 - 2018. [Online] Price Waterhouse Cooper. Available from: http: //www.pwc.com/gx/en/global-entertainm ent-media-outlook [Accessed: 12 July 2014]. Reczek, A. (2014) As 10 maiores redes do Brazil e como lidar com elas. [Online] Web Insider. 20 January 2014. Available from: http://webinsider.com.br/2014/01/20/as10-maiores-redes-do-brasil-e-como-lidarcom-elas/ [Accessed: 10 May 2014].

Rodrigues, L. (2014) 6 Tendencias Recentes em Redes Sociais no Brasil. [Online] Brasil Link. 13 August 2014. Available from: http://brasillink.usmediaconsulting.com/20 14/08/6-tendencias-recentes-em-redes-soci ais-no-brasil/ [Accessed: 10 September 2014].

Rosa, P. (2014) Unknown Title. Unknown Publication.

Russell, M. J. (2013) Trends. [Online] The Milken Institute Review. Available from: http://www.milkeninstitute.org/publications /review/2013_4/05-13MR58.pdf. [Accessed 15 January 2014].

Sallowicz, M. (2013) Acesso a internet no Brasil cresce, mas 53\% da população ainda não usa a rede. Folha de São Paulo [Online] $16^{\text {th }}$ May 2013. Available from: http://www1. 
folha.uol.com.br/mercado/2013/05/1279552acesso-a-internet-no-brasil-cresce-mas-53da-populacao-ainda-nao-usa-a-rede.shtml. [Accessed: 14 December 2013].

Salmon, A. (2013) Korea's S.M. Entertainment: The Company That Created K-Pop. [Online]. Forbes Magazine. 31 July 2013. Available from: http://www.forbes.com/sites/forbesasia /2013/07/31/koreas-s-m-entertainmentthe-company-that-created-k-pop/ [Accessed: 10 May 2014].

Seo, M.S. (2012a) Lessons from K-Pop's Global Success. [Online]. Available from: http:// www.seriquarterly.com [Accessed: 20 May 2014].

Seo, M.S. (2012b) What Business can learn from K-Pop for Global Strategy. Ceo Information N.841, February: Samsung Economic Research Institute.

Schnalke, M. and Mason, R. B. (2014) The influence of culture on marketing communications: critical cultural factors influencing South African and German businesses. Problems and Perspectives in Management. Vol. 12 (1).

Schwartz, R. (2011) Intercontinental Travel. Billboard: Vol. 123, Issue 46
Tudor, D. (2013) in Salmon, A. (2013) Korea's S.M. Entertainment: The Company That Created K-Pop. [Online]. Forbes Magazine. 31 July 2013. Available from: http://www. forbes.com/sites/forbesasia/2013/07/31/ koreas-s-m-entertainment-the-companythat-created-k-pop/ [Accessed: 10 May 2014]. Vicente, E. (2014) Estudo compara mercado musical independente britânico com brasileiro. [Online] Globo. 11 August 2014. Available from: http://redeglobo.globo.com/globouniver sidade/noticia/2014/08/estudo-comparamercado-musical-independente-britanicocom-brasileiro.html [Accessed: 01 September 2014].

Wheeler, A. (2012) Designing Brand Identity: An Essential Guide for the Whole Branding Team. $4^{\text {th }}$ Ed. Hoboken: John Wiley \& Sons.

Youtube (2014) Statistics. [Online] Youtube. Available from: http://www.youtube.com/ yt/press/statistics.html [Accessed: 18 July 2014].

Zarrella, D. (2010) The Social Media Marketing Book. Sebastopol: O’Reilly. 